\title{
STAT3 phosphorylation in central leptin resistance
}

\author{
Huimin Liu, Tianxin Du, Chen Li and Guoging Yang ${ }^{*}$
}

\begin{abstract}
Mechanism exploitation of energy homeostasis is urgently required because of the worldwide prevailing of obesityrelated metabolic disorders in human being. Although it is well known that leptin plays a central role in regulating energy balance by suppressing food intake and promoting energy expenditure, the existence of leptin resistance in majority of obese individuals hampers the utilization of leptin therapy against these disorders. However, the mechanism of leptin resistance is largely unknown in spite of the globally enormous endeavors. Current theories to interpret leptin resistance include the impairment of leptin transport, attenuation of leptin signaling, chronic inflammation, ER tress, deficiency of autophagy, as well as leptin itself. Leptin-activated leptin receptor (LepRb) signals in hypothalamus via several pathways, in which JAK2-STAT3 pathway, the most extensively investigated one, is considered to mediate the major action of leptin in energy regulation. Upon leptin stimulation the phosphorylation of STAT3 is one of the key events in JAK2-STAT3 pathway, followed by the dimerization and nuclear translocation of this molecule. Phosphorylated STAT3 (p-STAT3), as a transcription factor, binds to and regulates its target gene such as POMC gene, playing the physiological function of leptin. Regarding POMC gene in hypothalamus however little is known about the detail of its interaction with STAT3. Moreover the status of p-STAT3 and its significance in hypothalamus of DIO mice needs to be well elucidated. This review comprehends literatures on leptin and leptin resistance and especially discusses what STAT3 phosphorylation would contribute to central leptin resistance.
\end{abstract}

Keywords: Leptin resistance, STAT3 phosphorylation, Hypothalamus, DIO, Mechanism

\section{Introduction}

The greatly increased prevalence of type 2 diabetes and some metabolic diseases closely related with the rapidly growing obesity epidemic around the world, which due to an energy imbalance caused by unhealthy lifestyles and nutrient overload [1]. A better understanding of the mechanism underlying obesity is crucial in the battle against obesity. Increasing reports demonstrated that a vital risk factor for obesity is leptin resistance. However, the mechanisms that lead to leptin resistance are largely remains elusive. Emerging evidence provided insight into the role of signal transducer and activator of

*Correspondence: gqyang@yeah.net

College of Life Science, Henan Agricultural University, 95 Wen Hua Road, Zhengzhou 450002, China transcription 3 (STAT3) in energy metabolism. Therefore, elucidating the functions of STAT3 in energy metabolism and leptin resistance is necessary. In this review, the elaborate picture of STAT3 in leptin resistance is presented, which should help to facilitate the potential of STAT3 as a future therapeutic target.

\section{Leptin}

\section{Leptin discovery}

A complex control system of energy metabolism in vertebrates, especially mammalian species, has been established during the long period of evolution. The ability to store large quantities of energy against the food deprivation is on one hand crucial for survival, but on the other hand potential for the occurrence of metabolic problems in human beings because of food over-consumption and/ original author(s) and the source, provide a link to the Creative Commons licence, and indicate if changes were made. The images or other third party material in this article are included in the article's Creative Commons licence, unless indicated otherwise in a credit line to the material. If material is not included in the article's Creative Commons licence and your intended use is not permitted by statutory regulation or exceeds the permitted use, you will need to obtain permission directly from the copyright holder. To view a copy of this licence, visit http://creativecommons.org/licenses/by/4.0/. The Creative Commons Public Domain Dedication waiver (http://creativeco mmons.org/publicdomain/zero/1.0/) applies to the data made available in this article, unless otherwise stated in a credit line to the data. 
or lack of physical movement in modern life. Worldwide metabolic disorders like obesity, diabetes and cardiovascular diseases are on the rise, making endeavors in metabolism study an urgent task for scientists. A milestone in metabolism field is the discovery in 1994 made by Friedman and his colleagues, which convincingly showed that leptin are essential in regulating food intake and energy expenditure [2].

Leptin is a peptide hormone $(16-\mathrm{kDa})$ encoded by the obese $(o b)$ gene. It is mainly produced in the white adipose tissue, and secreted in proportion to fat mass [3, 4]. The discovery of leptin begins with a mouse model in the Jackson laboratory [5]; where the $o b$ gene was identified as a key regulator for obesity $[2,6]$. Subsequently, the protein product of the $o b$ gene was named "leptin" derived from the Greek word leptos, meaning "thin".

\section{Leptin function}

Leptin is a pleotropic hormone in energy metabolism. Animals without leptin signaling display severe metabolic imbalance. For example, mice with genetic deficiency of leptin $(\mathrm{ob} / \mathrm{ob})$ or leptin receptor gene $(\mathrm{db} / \mathrm{db})$ suffers from hyperphagia, severe obesity and diabetes, while administration of recombinant leptin from bacteria reverses these disorders in ob/ob, but not in $\mathrm{db} / \mathrm{db}$ mice, indicating leptin depends on its receptor for displaying functions [7]. The circulating leptin signals the status of body energy stores to the brain and induces the satiety responses through neurotransmmiters. Therefore, as a long-term regulator, leptin suppresses food intake to control the body weight.

Besides, leptin has been shown to promote energy expenditure particularly through its effects on the brown adipose tissue (BAT) thermogenesis via the hypothalamic. While ob/ob mice show low body temperature [8], leptin administration or the artificial activation of leptin receptor in hypothalamus increases metabolic activity of rodents with body weight loss [9]. This observation is consistent with the finding that leptin initiates the thermogenesis of BAT [10]. Hypothalamic administration of leptin elevates the level of blood catecholamine, suggesting that the leptin act on thermogenesis is through the sympathetic nervous system (SNS). However, it is still not clear how leptin regulate the activity of SNS via hypothalamus [11].

\section{Leptin signaling pathway}

\section{Leptin receptor and its signaling}

Leptin exerts biological actions by interacting with leptin receptors (LepRs) that is widely distributed in the brain and peripheral tissues [12, 13]. The central nervous system (CNS), especially the hypothalamus, rather than peripheral tissues, is identified to be the main leptin target for the regulation of physiological functions [14]. Multiple splice variants of LepR gene encode at least six different LepRs isoforms, which have an identical extracellular leptin-binding domain at $\mathrm{N}$-terminal but different intracellular domains at the C-terminal [15]. The isoforms are divided into three types: short (LepRa, c, $\mathrm{d}$, and $\mathrm{f}$ ), long (LepRb), and secreted (LepRe) forms [16] (Fig. 1). Only LepRb contains the domain required for JAK-STAT signaling pathway [17-19]. As expected, db/ $\mathrm{db}$ mice which harbors mutated lepRb display a phenotype similar to leptin-deficient ob/ob mice, suggesting that LepRb is the most critical in mediating leptin's actions [14]. Short-form LepRs may be involved in leptin transport and leptin clearance $[20,21]$, and LepRe is the soluble secreted one [22].

Activation of LepR directly or indirectly activates multiple signaling pathways, including Janus tyrosine kinase 2 (JAK2)/STAT3, srchomology-2-containing protein tyrosine phosphatase 2 (SHP2)/growth factor receptor-bound protein $2(\mathrm{Grb} 2) /$ mitogen-activated protein kinase (MAPK), forkhead box O1 (FoxO1), $5^{\prime}$ adenosine monophosphate-activated protein kinase (AMPK) and others. These pathways act synergistically to fully mediate leptin function (Fig. 2). Of these, JAK2/STAT3 pathway is the best characterized. Functional LepRb belongs to the type I family of cytokine receptors without the activity of an internal kinase [23]. Binding of leptin to LepRb initiates a cascade of signaling pathway beginning with the activation of JAK2, which is in turn autophosphorylated. The activated JAKs, especially JAK2 stimulates the phosphorylation of the three residues on the intracellular domain of LepRb $\left(\mathrm{Tyr}_{985}, \mathrm{Tyr}_{1077}\right.$ and $\left.\mathrm{Tyr}_{1138}\right)$. Each of the three phosphorylation sites recruits distinct downstream signaling molecules, and induces a leptin-specific signaling pathway with diverse physiological actions [24].

\section{JAK2/STAT3 signaling}

In response to leptin, JAK2 activated LepRb on $\mathrm{Tyr}_{1138}$ and phospho-Tyr ${ }_{1138}$ binds to the Src homology 2 (SH2) domain of STAT3, which is then phosphorylated via LepRb-associated of JAK2 [25, 26]. Phosphorylated STAT3 is translocated from the cytoplasm into the nucleus, where it acts as a transcription factor to regulate the expression of its target genes, including suppressor of cytokine signaling 3 (SOCS3) and neuropeptides [27, 28]. Numerous genetic evidence demonstrates that the JAK2/ STAT3 signaling appears to play a major role in energy homeostasis and neuroendocrine function. Furthermore, a specific deletion of $\mathrm{Tyr}_{1138}$ in LepRb or STAT3 in LepRb-expressing neurons leads to hyperphagia and obesity similar to the phenotype observed in $\mathrm{db} / \mathrm{db}$ mice [29], suggesting that $\mathrm{Tyr}_{1138}$ in STAT3 is vital for leptin action. 


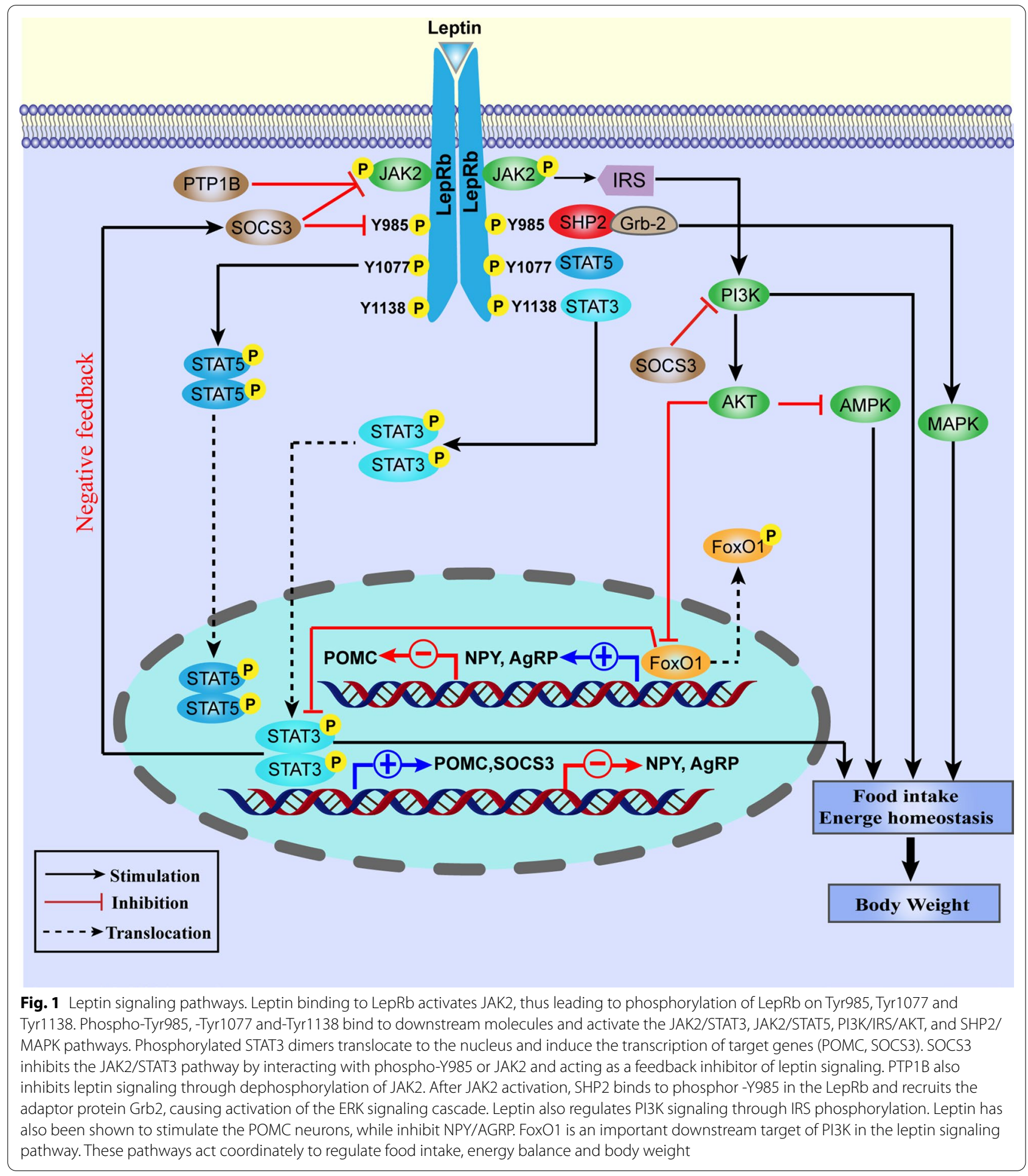

\section{JAK2/STAT5 signaling}

Leptin stimulates LepRb phosphorylation on Tyr1077, and phosphorylated $\mathrm{Tyr}_{1077}$ binds to the $\mathrm{SH} 2$ domain of STAT5 and makes it phosphorylated and activated by JAK2 [30]. Phospho-Tyr1138 also partially contributes to STAT5 activation [31]. Mice with a STAT5 deletion in the brain causes hyperphagia and obesity, whereas activation of STAT5 in hypothalamic neurons inhibits food intake [32], but less severely than in mice with a STAT3 deletion, suggesting that the JAK2/STAT5 signaling plays 


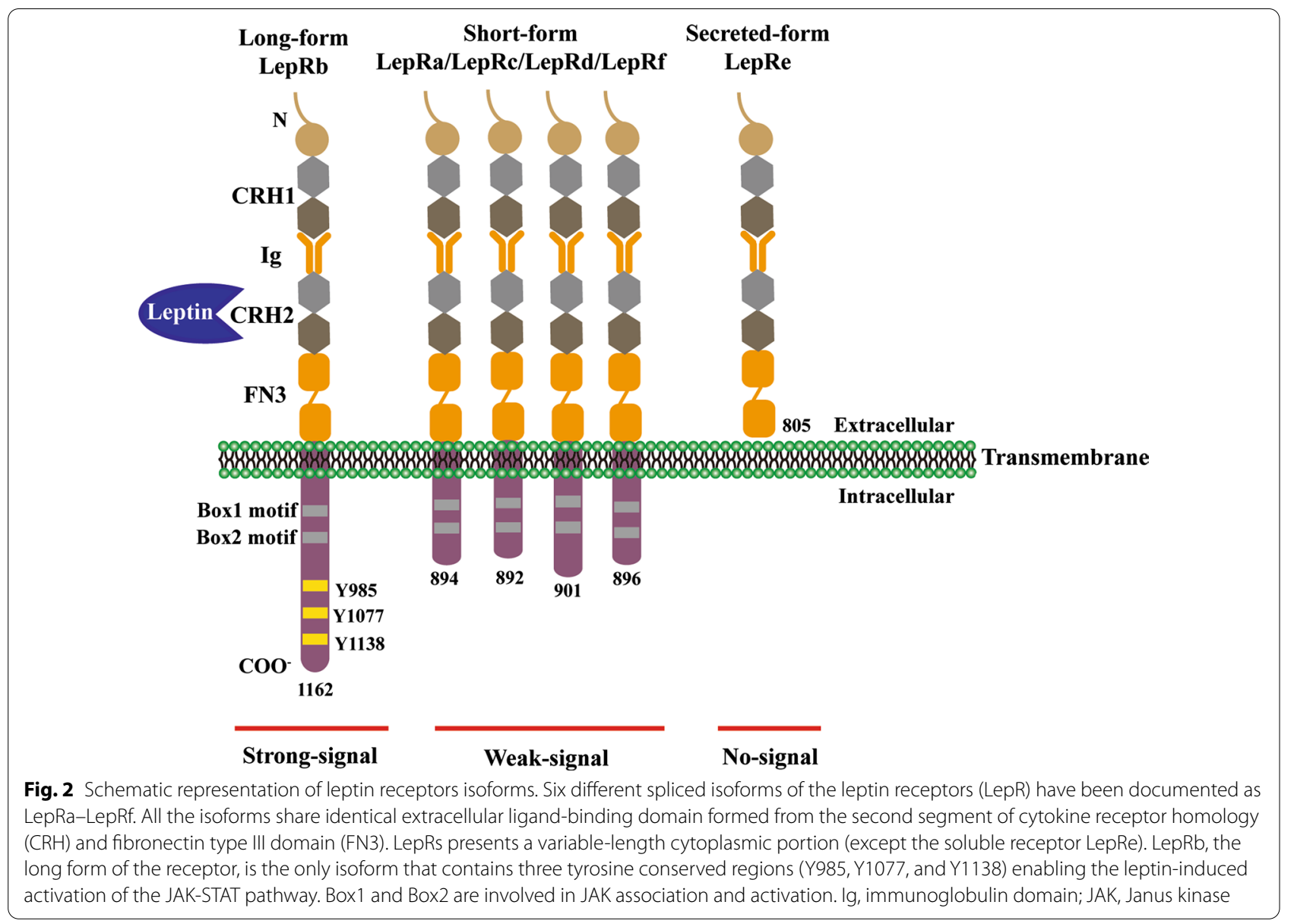

a minor role in leptin's regulation of feeding and body weight [33]. A recent research reveals that ablation of STAT5 in LepRb neurons fails to change energy balance [34].

\section{SHP2/ERK signaling}

Phosphorylation of $\mathrm{Tyr}_{985}$ activates signaling related with SH2-containing protein tyrosine phosphatase 2 (SHP2) and mediates the leptin-stimulated activation of the extracellular signal-related kinase (ERK) pathway, which executes the important functions in thermogenesis and anti-obesity of leptin $[35,36]$. SHP2 may also downregulate JAK2/STAT3 signaling under some conditions [37]. Neuron-specific deletion of the SHP2 results in obesity and leptin resistance in mice, suggesting that the SHP2 pathway is also important in mediating leptin's antiobesity action [38]. Phospho-Tyr985 also binds to the $\mathrm{SH} 2$ domain of SOCS3, and SOCS3 in turn inhibits the activation of the LepRb/JAK2 pathways [39]. One study reported that ablation of Tyr985 phosphorylation by a replacement of Tyr985 with Phe promotes diet-induced leptin resistance and obesity [40]. Surprisingly, another study reported that elimination of Tyr985 phosphorylation protects against diet induced obesity in female mice [41]. It is likely that the levels of intracellular SOCS3 may contribute to the outcome of phosphorylation of Tyr985.

\section{STAT3 in JAK2/STAT3 signaling pathway of leptin}

\section{Structure and function of STAT3}

The STATs, a family of transcription factors (STAT1, 2, 3, $4,5 \mathrm{a}, 5 \mathrm{~b}$, and 6) [42], exert vital functions in signal transduction and transcriptional regulation [43-45]. STAT3, a member of STATs, was first identified in 1994 and is highly conserved [46]. Similar to other STAT proteins, STAT3 is composed of the 6 domains: $\mathrm{N}$-terminal dimerization domain (ND), coiled-coil domain (CCD) for protein-protein interactions, central DNA-binding domain (DBD), linker domain (LD) that affects DNA-binding stability, SH2 domain essential for STAT3 activation, and a C-terminal transcriptional activation domain (TAD) with a conserved tyrosine residue at 705 (Tyr705) and a serine phosphorylation site at 727 (Ser727) [47].

Additionally, STAT3 has been identified as having four distinct subtypes: STAT3 $\alpha(92 \mathrm{kDa})$, STAT3 $\beta$ ( $83 \mathrm{kDa})$, 
STAT3y $(72 \mathrm{kDa})$ and STAT3 $\delta(64 \mathrm{kDa})$, which are regarded a pivotal determinant of STAT3 functional heterogeneity [48-50]. STAT3 $\beta$, an alternative splicing transcript of full-length STAT3 $\alpha$, replaces the C-terminal 55 amino acids with 7 specific amino acid tail (Fig. 3), leading to greater DNA binding activity [51]. Notably, it has been recently proved that STAT3 $\beta$ has distinct regulatory and transcriptional functions, which might have a suppressive effect on STAT3 [51-53]. STAT3 $\alpha$ exert its functions in modulation of cellular responses to IL-6 and IL-10 in macrophages [54]. STAT3y and STAT38, the other two STAT3 isoforms, are derived from the proteolytic processing of STAT3, which were mainly activated in different stages of granulocytic differentiation [48] (Table 1).

\section{STAT3 targets in neurons}

The hypothalamus is considered a key organ in the regulation of food intake. Leptin primarily acts on the hypothalamic arcuate nucleus (ARC) neurons producing orexigenic neuropeptide Tyr (NPY)/Agouti-related protein (AgRP) and anorexigenic proopiomelanocortin $(\mathrm{POMC}) /$ amphetamine-regulated transcript (CART) $[55,56]$. Leptin promotes POMC gene expression and
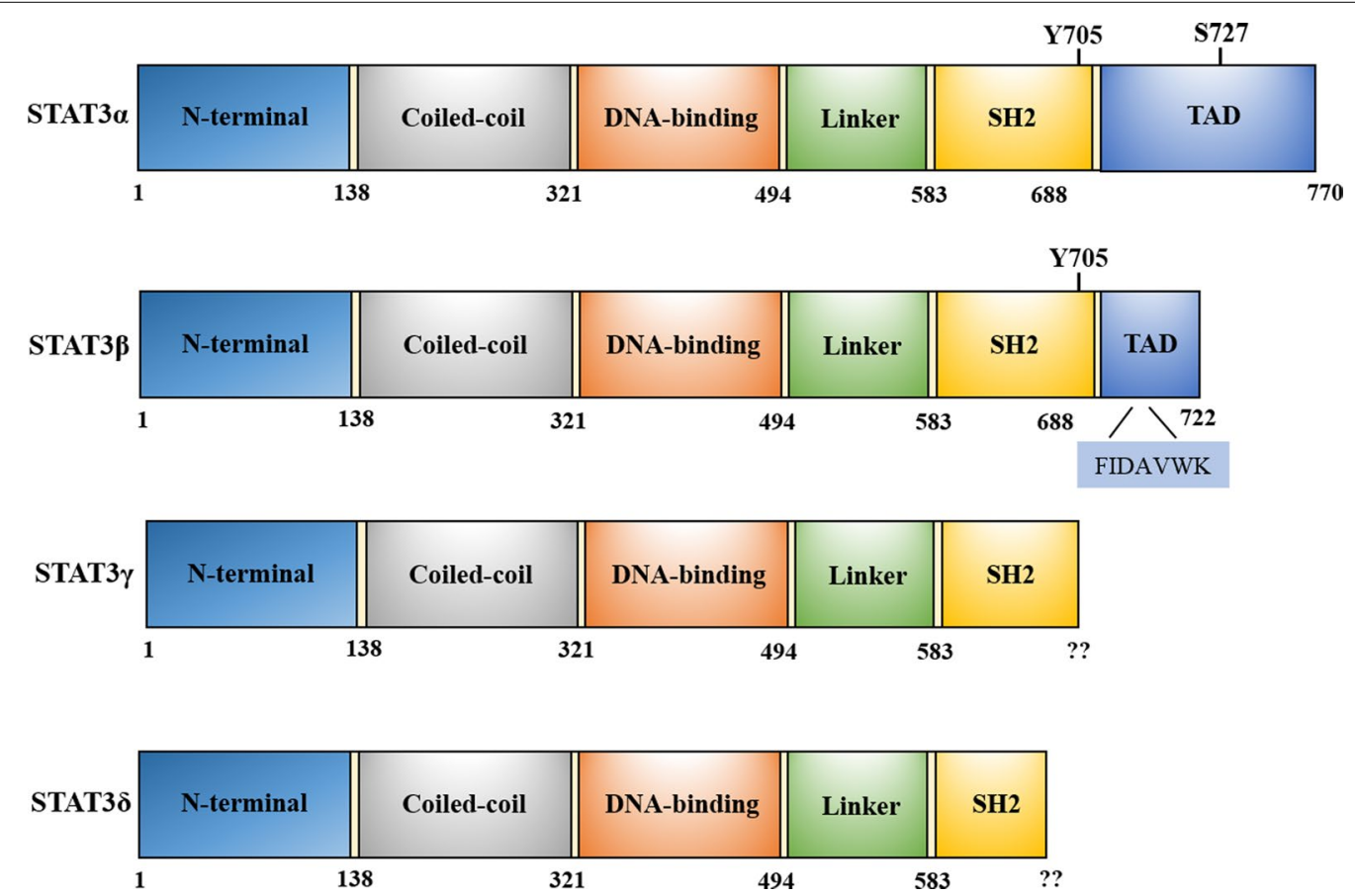

Fig. 3 Schematic representation of STAT3 isoforms domains. STAT3 structure is composed by a helical N-terminus domain (NTD); a coiled-coil domain (CCD); a central DNA-binding domain (DBD); a linker domain (LD); an Src homology 2 (SH2) domain; and a C-terminal transactivation domain (TAD) with a conserved tyrosine residue at 705 (Y705) and a serine phosphorylation site at 727(S727)

Table 1 STAT3 isoforms

\begin{tabular}{|c|c|c|c|c|}
\hline STAT3 isoform & $\begin{array}{l}\text { Molecular } \\
\text { weight } \\
(\mathrm{kDa})\end{array}$ & Structure & Function & References \\
\hline STAT3a & 92 & Full length & Typical STAT3 function & {$[47]$} \\
\hline STAT3 $\beta$ & 83 & C-terminal truncated form (missing Ser727) & $\begin{array}{l}\text { Greater DNA binding activity; Distinct regulatory } \\
\text { and transcriptional functions; Suppressive effect } \\
\text { on STAT3 }\end{array}$ & {$[51]$} \\
\hline STAT3 $\gamma$ & 72 & $\begin{array}{l}\text { C-terminal truncated form (missing Ser727and } \\
\text { Tyr705) }\end{array}$ & $\begin{array}{l}\text { Activated in the terminal stage of granulocytic dif- } \\
\text { ferentiation }\end{array}$ & {$[48]$} \\
\hline STAT3 $\delta$ & 64 & $\begin{array}{l}\text { C-terminal truncated form (missing Ser727 and } \\
\text { Tyr705) }\end{array}$ & $\begin{array}{l}\text { Activated in the early stage of granulocytic differen- } \\
\text { tiation }\end{array}$ & {$[48]$} \\
\hline
\end{tabular}


activates POMC neurons [57-59], while decreases AgRP gene expression and inhibits AgRP neurons [60, 61]. Consistently, $o b / o b$ and $d b / d b$ mice display elevated levels of AgRP mRNA and reduced levels of POMC mRNA $[62,63]$. Ablation of AgRP neurons and decrease in AgRP gene expression lead to lean mice [64,65]. Conversely, deletion of POMC neurons and loss of POMC-derived transmitters result in obesity $[65,66]$. This underlines the importance of leptin-stimulated POMC and AgRP neuron regulation in the control of food intake and energy homeostasis [67]. In addition, leptin has also been shown to stimulate the expression of the transcription factor steroidogenic factor-1 (SF-1) neurons in the ventromedial hypothalamus (VMH), leading to inhibition of feeding [68]. Like hypothalamic neurons, the nucleus tractus solitaries (NTS) POMC neurons showed the STAT3 activation in response to exogenous leptin [69].

Leptin-stimulated STAT3 dimer binds to the POMC and AgRP promoters in the nucleus, which stimulates the expression of POMC and suppresses that of AgRP, thereby decreasing food intake and increasing energy expenditure. There are two STAT3 binding sites in POMC promoter, the distal $(-361$ to -353$)$ and the proximal $(-76$ to -68$)$. With regard to POMC gene regulation, it has been reported that the POMC promoter contains forkhead DNA-binding sites adjacent to distal site, and FoxO1 competes with STAT3 for binding to neighboring DNA sequences in the POMC promoter, thereby inhibiting leptin-mediated POMC expression [70]. However, we [71] and other [72] demonstrated in the cultured cells that deletion of the distal STAT3-binding site had little effect, but the removal of the proximal one dramatically abrupt leptin regulation of POMC promoter activity.

Numerous mouse models with neuronal ablation of STAT3 have been proved essential roles of STAT3 in energy homeostasis regulation. Neural-specific disruption of STAT3 (STAT3 $^{\mathrm{N}-/-}$ ) in mice [73] and mice with mutated leptin receptors that do not bind STAT3 [29] are hyperphagic, and obese with decreased energy expenditure, and show raised mRNA levels of AgRP. Interestingly, it has been reported that leptin-activated STAT3 is not required for the development of leptin response in the AgRP neurons [74, 75]. Notably, mice deficient of STAT3 in AgRP neurons appears to have no change in the mRNA levels of AgRP [76]. The deletion of STAT3 in the CNS leads to severe obesity with accompanying decreased POMC expression [73], whereas STAT3 inactivation in POMC neurons causes slight obesity and diminished POMC expression, which suggest STAT3 as a transcriptional activator of POMC expression [77]. Similarly, the disruption of STAT3 in POMC or/and AgRP neurons provokes only modest effects on food intake and body weight $[77,78]$. Therefore, although LepRb-expressing POMC and AgRP neurons are both crucial for leptin action, to a large extent, LepRb in these neurons is dispensable [79].

\section{STAT3 activation}

In unstimulated cells, STAT3 is inactive and presents as monomer in the cytoplasmic [54, 80]. Once activated by various types of stimuli, phosphorylated STAT3 translocate into the nucleus to initiate transcription via binding to the promoter sequence of target genes. Moreover, it has been reported that STAT3 nuclear import may be independently of its phosphorylation and mediated by specific import carrier- $\alpha 3$ [81]. Therefore, STAT3 can exert functions by formation of phosphorylated STAT3 (p-STAT3) dimers as well as enhanced amounts of unphosphorylated STAT3 in cytokine-dependent transcription.

Apart from the classical pathway through JAKs, STAT3 can also be phosphorylated by some receptor tyrosine kinase (RTKs) and other non-receptor kinases (e.g., Src and Abl) [42]. Significantly, RTKs can directly activate STAT3 by independently of JAKs, and can also phosphorylate STAT3 by constitutively active non-receptor kinases [82]. In addition to tyrosine 705 phosphorylation, which is considered as a critical role in STAT3 activation, STAT3 is also active via serine (Ser727) phosphorylation by the MAPK or mTOR pathways [83, 84]. Moreover, recent evidence has identified that the reversible acetylation of STAT3 by histone deacetylases on lysine residue 685 provides a novel alternative mechanism of STAT3 activation [85].

\section{STAT3 inhibition}

Negative regulators of STAT3 pathway, involving protein tyrosine phosphatases (PTPs), protein inhibitors of activated STAT (PIAS), and suppressor of cytokine signaling 3 (SOCS3), can inhibit STAT3 activity. CD45, a transmembrane PTP, inhibit STAT3 activity via dephosphorylation of JAKs [86]. PTP-1B, a non-transmembrane PTP, down-regulate leptin/STAT3 signaling via indirectly inactivating JAK2, which may be a new target for the treatment of obesity induced by leptin resistance [87]. SH2-containing protein tyrosine phosphatase (SHP-1 and SHP-2) can dephosphorylate and inactivate STAT3 by binding to the phosphorylation site of STAT3 [88]. PTP receptor T (PTPRT) specifically dephosphorylates STAT3 at Tyr705, thereby regulating cellular localization and expression of target genes [89]. In short, STAT3 activation is regulated by PTPs through direct and indirect dephosphorylation of p-STAT3. Moreover, PIAS3 binds to the STAT3 DNA binding domain and blocks the STAT3 transcriptional activity [90]. Additionally, SOCS3 
act as negative feedback regulator of the JAK2/STAT3 signaling pathway by blocking STAT3 activation. The mechanisms involved in JAK2/STAT3 signaling inhibited by SOCS3 have been suggested, such as kinase-mediated inhibition of JAKs via the kinase inhibitory region (KIR) domain, binding site competitors of STAT3 for initiating JAKs, or degradation via the SOCS box [91, 92].

Another negative regulator Forkhead box O1 (FoxO1) is upregulated during early stages of diet-induced leptin resistance. Mice with ablation of FoxO1 in the POMC neurons are resistant to diet-induced obesity [93]. Our previous research demonstrated that FoxO1 inhibits STAT3 activation by preventing STAT3 from binding to specificity protein 1 (SP1)-POMC promoter complex, hence reducing POMC expression [94]. Various lines of evidence have suggested that direct FoxO1-STAT3 interaction is necessary for FoxO1 inhibition of POMC promoter activation.

\section{Leptin resistance}

Leptin resistance defined by a failure response to high circulating leptin level, presenting a decreased capacity of leptin to suppress appetite or increase energy cost, leads to overweight, obesity and other metabolic disorders [95]. Leptin resistance is a main risk factor of obesity in humans [96]. To date, although much research work has been conducted in diet-induced obesity (DIO) micewith leptin resistance, the molecular mechanisms largely remains elusive. However, several theories have been put forth.

\section{Impairment in leptin transportation}

Reduced leptin transportation into the brain is considered as an important factor for leptin resistance [97]. To exert its actions, leptin needs to be transported into the brain across the blood-brain barrier (BBB) by a specific and saturable protein transporter [98] (Fig. 4). In this process, the LepRb is required and animal experiment shows the loss of LepRb reduces the quantity of leptin in the brain [99]. Hence, if the leptin level is excessively high, it may lead to LepRb saturation and further reduce the ratio of leptin transport via the $\mathrm{BBB}$, finally causing leptin resistance [100] (Fig. 4b). Interestingly, several studies found the loss of leptin transporters do not lead to the decrease in the amount of leptin crossing the BBB $[101,102]$, but the molecular mechanism involved is still poorly understood. However, it is debatable whether leptin resistance is unrelated to transportation, due to decrease in leptin transport in obese subjects via the $\mathrm{BBB}$. In a recent study, no difference was shown in leptin accumulation between obese and lean mice in the brain by visualizing leptin transportation into the brain with 3D imaging from lightsheet fluorescence microscopy
[103]. Additionally, several factors have been determined to affect leptin transport. For example, epinephrine can enhance the leptin transportation across the BBB [104], whereas lipopolysaccharide [105], obesity [106], triglycerides [107], and fasting [108] largely reduce the rate of transport.

\section{Attenuation of leptin signaling}

Defect in any element of the LepRb signaling pathway is expected to contribute to leptin resistance [109]. The decreased hypothalamic LepRb number and certain mutations of the $L e p R b$ gene with the truncated intracellular domain of LepRb, attenuate LepRb-mediated leptin signaling [18]. The upregulation of the negative regulators may diminish the leptin signaling, which is involved in the pathogenesis of leptin resistance $[110,111]$. Additionally, the feedback inhibition and downregulation or inhibition of positive regulators of leptin signaling may also lead to leptin resistance [112-114].

\section{Deficiency in autophagy}

Increasing evidence suggest the leptin-autophagy interaction plays a crucial role in the regulation of energy homeostasis. Ablation of autophagy-related protein 7 (Atg7) in the hypothalamus shows increased food intake and body weight, obesity and leptin resistance [115]. Moreover, Atg7-knockout mice exhibit leptin resistance due to the failure of leptin to activate STAT3 [116]. In contrast, mice with specific deletion of Atg7 in AgRP neurons showed reduced food intake and body fat, as well as a long term effect on energy homeostasis, suggesting improvement in leptin sensitivity [117]. Notably, a recent study indicated that leptin may contribute to the dysregulated/activated adipocyte autophagy and to its dysfunction in obesity [118].

\section{Endoplasmic reticulum stress and Inflammation}

Endoplasmic reticulum (ER) stress and inflammation could impair leptin responsiveness of neuronal cells by blocking leptin signaling (Fig. 4). Recently, ER stress and the unfolded protein response (UPR) have emerged as a crucial link in the development of leptin resistance [119-121]. In particular, obese mice present ER stress in POMC neurons and peripheral tissues, suggesting that ER stress is induced by metabolic disorders related with obesity and HFD [122-124]. Notably, IKK $\beta / N F-\kappa B$ is activated by HFD through elevated ER stress in the hypothalamus, which leads to leptin resistance [125]. Moreover, IKK $\beta$ expression enhances SOCS3 promoter activity, and this process is controlled by NF- $\mathrm{kB}$. High fat diet (HFD) significantly induces SOCS3 in hypothalamus [125]. 
Induction of ER stress or deletion of the X-box binding protein 1 (Xbp1), a UPR transcription factor, results in leptin resistance and promotes weight gain on a HFD [119]. In contrast, the constitutive activation of Xbp1 in POMC neurons prevents against DIO and enhances leptin sensitivity [126]. Furthermore, ER stress inhibits leptin signaling in the hypothalamus via classical inhibitors of cytokine signaling (i.e. SOCS3 and PTP1B) [16, 127, 128] (Fig. 4). In line with this, ER stress can impair leptin signaling by blocking leptin-induced STAT3 phosphorylation, which is increasingly considered to be associated with leptin resistance $[119,120,129]$. It is noteworthy that a recent research demonstrated that leptin deficiency can cause elevated ER stress, while relieving ER stress can ameliorate metabolic regulation [130].

\section{Leptin-induced leptin resistance}

Leptin itself is also a contributing factor in the development of leptin resistance, with this state termed "leptin-induced leptin resistance" [131]. The chronically augmented leptin in the CNS contributes to leptin resistance, which further promotes obesity, resulting in a vicious cycle of escalating metabolic disorder. Longterm exposure to hyperleptinemia causes leptin resistance by downregulating cellular response to leptin [132]. In contrast, low levels of plasma leptin highly ameliorates leptin sensitivity, yet does not prevent DIO [133]. Leptin sensitivity can be restored in mice by inhibiting leptin production in adipocyte and increasing leptin clearance in kidney [134]. Of note, triglycerides plays vital role in the leptin resistance to peripheral leptin on account of its inhibition of leptin transport across the BBB [97].

\section{Others}

Apart from above-mentioned mechanisms, other factors also contribute to the leptin resistance. C-reactive protein (CRP) can increase BBB permeability, but augmented CRP may promote leptin resistance by blocking the binding of leptin to correspondent receptor [135]. Other potential mechanisms behind leptin resistance may be related to epigenetic remodeling [136]. More
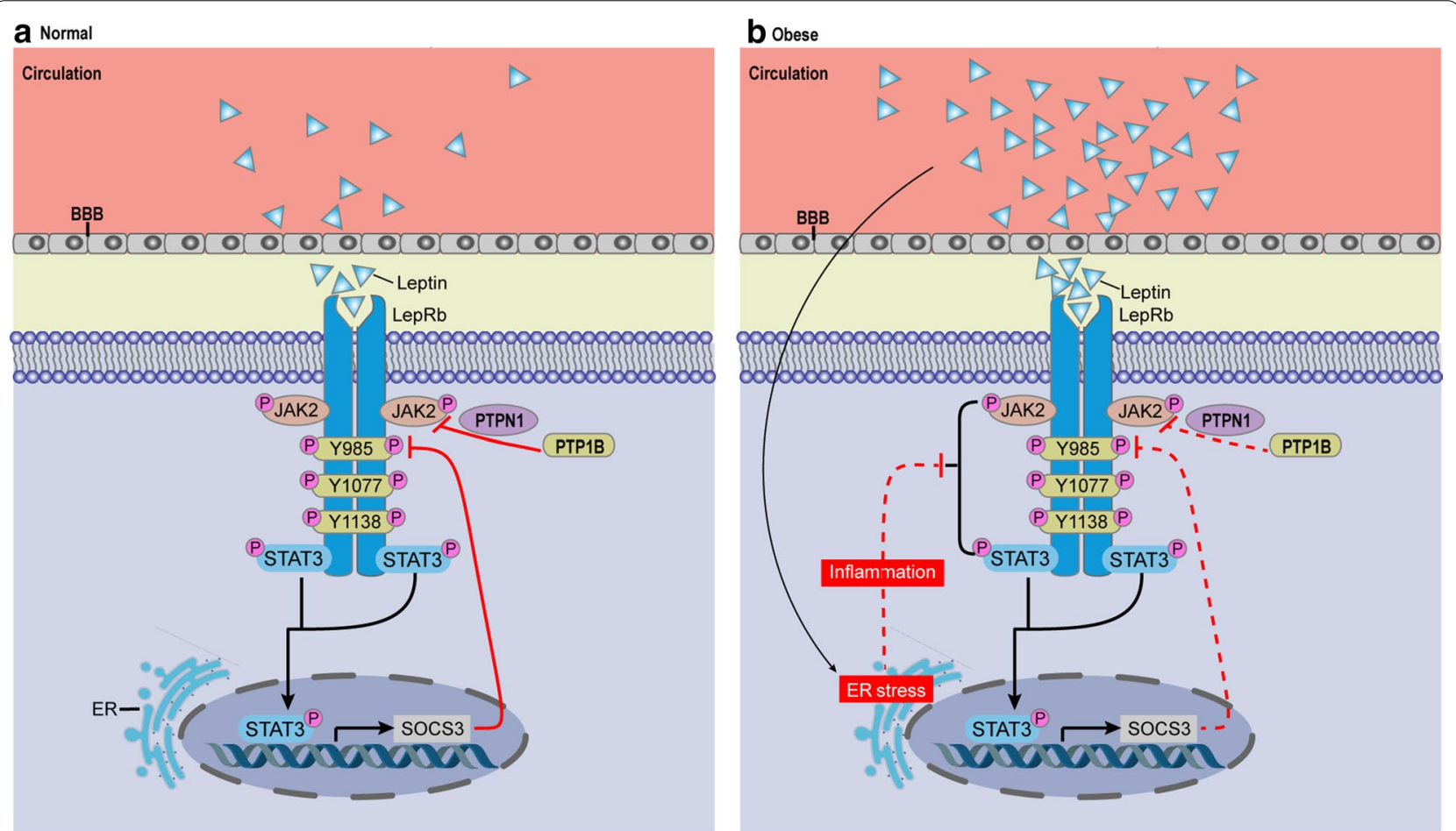

Fig. 4 Mechanisms of Leptin resistance. a In animals with normal body weight, circulating leptin crosses the BBB and binds to LepRb, which induces phosphorylation of JAK2 and of multiple tyrosine residues in the LepRb intracellular domain. LepRb also receives inhibitory signals from multiple negative feedback loops, including SOCS3, PTP1B, ensuring that activation of LepRb does not go beyond a physiologically necessary point. $\mathbf{b}$ In obesity, circulating levels of leptin increase, which is associated with diminished leptin transport across the BBB and activation of the inhibitory negative feedback systems that eventually lead to diminished LepRb signaling. Many factors, including hyperleptinemia, inflammation, endoplasmic reticulum (ER) stress, inflammatory and defective autophagy, contribute to leptin resistance. ER stress and responses might contribute to a blunted physiological response to leptin in obesity 
in-depth studies are required to further elucidate the mechanisms of leptin resistance.

\section{STAT3 phosphorylation in hypothalamus of DIO mice}

STAT3 is specifically activated by leptin in vivo and in vitro. But how STAT3 regulates leptin's biological activity has not been determined. Genetic STAT3 null or STAT3 phosphorylation deficiency in hypothalamus causes central leptin resistant and severe obesity animal $[27,137]$. Leptin-activated STAT3 phosphorylation, as proved in the hypothalamus of lean wild-type animal [138], becomes a marker frequently employed in the assessment of central leptin signaling in the case of leptin resistance [15], similar to the situation in most obesity of humans and rodents of DIO [109]. Although a large portion of the mechanisms of leptin resistance remains to be identified, it raises a simple and salient question on whether the leptin-stimulated STAT3 activity is abated in the hypothalamus in DIO mice.

Most scientists claim that pSTAT3 induced by exogenous leptin treatment are reduced in the hypothalamus of DIO mice [139] evidenced mainly by the results from three different kind of investigations, and believe this decrease contributes to the mechanism of central leptin resistance [72, 140-146]. While immunohistochemical stain of STAT3 detects the local STAT3 distribution, arcuate nucleus (ARC) of hypothalamus is considered as the main leptin target for energy regulation [147], in spite of hypothesis that the anorectic effects of leptin are not specific from a brain region [148, 149]. In the majority of experiments using p-STAT3 immunohistochemistry, exogenous leptin-induced p-STAT3 increases in the ARC of lean mice, but not in that of DIO mice [109]; Western blot analysis is another method commonly employed in the detection of hypothalamic p-STAT3. The result of immunoblotting of hypothalamic arcuate nuclei lysate with the antibody against p-STAT3 demonstrates that leptin-activated STAT3 phosphorylation is blunted by $60 \%$ in the hypothalamus of leptin-resistant mice prepared by palmitate treatment [141]. The third approach for this purpose is eletrophoretic mobility shift assay (EMSA), which is a method to detect the DNA-binding activity of a certain protein. With DNA probe M67-SIE (cis inducible element) STAT3 activation is detected [26] in hypothalamus of lean mice, but not in that of DIO mice in response to exogenous leptin administration [145]. However, our previous work demonstrated that p-STAT3 induced by exogenous leptin treatment are increased in the hypothalamus of DIO mice, which may contributes to the mechanism of central leptin resistance [71].

Thus, if the onset and/or development of central leptin resistance results from the impairment of hypothalamic
STAT3 activation, it is conceivable that the enhancement of STAT3 activity would somehow ameliorate this disorder. Whereas Ernst et al. reports the contrary result that high level of activated STAT3 in hypothalamus of the transgenic mice results in leptin resistance [133], it remains necessary to reevaluate the degree of STAT3 activation in hypothalamus of DIO mice in response to leptin administration and its effect on subsequential events such as POMC expression. Inconsistent to the prevailing consensus, Martin et al. showed that basal STAT3 phosphorylation is significantly elevated in arcuate of DIO mice [150]. In our previous report, we provided novel evidences from EMSA that both basal and exogenously leptin-mediated STAT3 activity was significantly elevated in the hypothalamus of DIO mice accompanied with decreased POMC expression and abnormal behaviors of metabolic physiology, suggesting that enhanced STAT3 activity negatively regulated leptin-mediated POMC expression in DIO mice. Furthermore, reduction of p-STAT3 by manual intervention furthered the leptin-mediated expression of POMC gene in the cultured cells, in line with the idea that p-STAT3 plays a negative role in hypothalamus of DIO mice [71]. Futhermore, evidences exist that excess STAT3 activity negatively regulated POMC expression in hypothalamus of DIO mice, suggesting the attenuation of STAT3 activity may facilitate leptin signaling [71]. Interestingly, over-expression of constitutively-active STAT3 in LepRb neurons leads to negative energy balance in ob/ob and wild-type mice, but not in DIO mice [34].

\section{Perspective}

Central leptin resistance is one of the major problems in obese people. Currently investigation into the mechanism leads to diverse conclusion in terms of whether leptin contributes to the sensing of overfeeding-made fat expansion $[151,152]$. Considering the essential role of the leptin axis to energy homeostasis in animals and humans has been convincingly established, we believe that a better understanding of the mechanism of signaling impairment is warranted. While basic question like the rising or descending of phosphor-STAT3 in hypothalamus of DIO mice is being debated, possibility still remains that leptin axis is able to sense overfeeding fat expansion. We previously proved that both basal and exogenously leptin-mediated STAT3 activity was significantly elevated in the hypothalamus of DIO mice, and speculated that leptin resistance happens downstream of STAT3 activation in the JAK2-STAT3 pathway of leptin signaling. Therefore, fully understanding of the detailed action of phosphor-STAT3 in hypothalamus will be of great significance. We propose that some unknown factor(s), which are abundant in hypothalamus of normal mice but 
gradually missed along the development of diet-induced obesity, would be necessary for phosphor-STAT3 to act on its target genes. The identification of these factors and the experimental evidences of direct interaction between phosphor-STAT3 and its target gene would hopefully illuminate our way to overcome leptin resistance and metabolic disorders.

\begin{abstract}
Abbreviations
STAT3: Signal transducer and activator of transcription 3; SHP2: SH2-containing protein tyrosine phosphatase 2; SOCS3: Suppressor of cytokine signaling 3; PTP1B: Protein tyrosine phosphatase 1B; DIO: Diet-induce obesity; PI3K: Phosphatidylinositol 3 kinase; MAPK: Mitogen-activated protein kinase; FoxO1: Forkhead box 01; IRS: Insulin receptor substrate; Grb2: Growth factor receptorbound protein 2; CART: Cocaine- and amphetamine-regulated transcript; POMC: Proopiomelanocortin; AgRP: Agouti-related protein; NPY: Neuropeptide Y; VMH: Entromedial hypothalamus; NTS: Nucleus tractus solitaries; SF-1: Transcription factor steroidogenic factor 1.
\end{abstract}

\section{Acknowledgements}

None.

\section{Authors' contributions}

Prof. HL and GY conceived together the review. TD and CL preformed literatures extraction and analysis. HL wrote the manuscript under the guidance of Prof. GY. All authors have read the manuscript and approved the manuscript.

\section{Funding}

This work was supported by National Natural Science Foundation of China (No. 31902268).

\section{Availability of data and materials}

Not applicable.

\section{Declarations}

Ethics approval and consent to participate

Not applicable.

\section{Consent for publication}

Not applicable.

\section{Competing interests}

The authors declare that they have no competing interests.

Received: 19 January 2021 Accepted: 3 April 2021

Published online: 13 April 2021

\section{References}

1. Kopelman PG. Obesity as a medical problem. Nature. 2000;404:635-43.

2. Zhang Y, Proenca R, Maffei M, Barone M, Leopold L, Friedman JM. Positional cloning of the mouse obese gene and its human homologue. Nature. 1994;372:425-32.

3. Farr OM, Gavrieli A, Mantzoros CS. Leptin applications in 2015: what have we learned about leptin and obesity? Curr Opin Endocrinol Diabetes Obes. 2015;22:353-9.

4. Münzberg $H$, Morrison CD. Structure, production and signaling of leptin. Metabolism. 2015;64:13-23.

5. Ingalls AM, Dickie MM, Snell GD. Obese, a new mutation in the house mouse. Obes Res. 1996;4:101.

6. Coleman DL. Effects of parabiosis of obese with diabetes and normal mice. Diabetologia. 1973;9:294-8.
7. Halaas JL, Gajiwala KS, Maffei M, Cohen SL, Chait BT, Rabinowitz D, Lallone RL, Burley SK, Friedman JM. Weight-reducing effects of the plasma protein encoded by the obese gene. Science. 1995;269:543-6.

8. Harris R, Zhou J, Redmann S, Smagin G, Smith S, Rodgers E, Zachwieja J. A leptin dose-response study in obese (ob/ob) and lean (+/?) mice Endocrinology. 1998;139:8-19.

9. Rezai-Zadeh K, Yu S, Jiang Y, Laque A, Schwartzenburg C, Morrison CD, Derbenev AV, Zsombok A, Münzberg H. Leptin receptor neurons in the dorsomedial hypothalamus are key regulators of energy expenditure and body weight, but not food intake. Mol Metab. 2014;3:681-93.

10. Enriori PJ, Sinnayah P, Simonds SE, Rudaz CG, Cowley MA. Leptin action in the dorsomedial hypothalamus increases sympathetic tone to brown adipose tissue in spite of systemic leptin resistance. J Neurosci. 2011;31:12189-97.

11. Friedman JM. Leptin and the endocrine control of energy balance. Nat Metab. 2019;1:754-64.

12. Gautron L, Elmquist JK. Sixteen years and counting: an update on leptin in energy balance. J Clin Investig. 2011:121:2087-93.

13. Scott MM, Lachey JL, Sternson SM, Lee CE, Elias CF, Friedman JM, Elmquist JK. Leptin targets in the mouse brain. J Comp Neurol. 2009;514:518-32.

14. Bates SH, Myers MG Jr. The role of leptin receptor signaling in feeding and neuroendocrine function. Trends Endocrinol Metab. 2003:14:447-52.

15. Morris DL, Rui L. Recent advances in understanding leptin signaling and leptin resistance. Am J Physiol Endocrinol Metab. 2009;297:E1247-1259.

16. Myers MG, Cowley MA, Münzberg H. Mechanisms of leptin action and leptin resistance. Annu Rev Physiol. 2008;70:537-56.

17. Baumann H, Morella KK, White DW, Dembski M, Bailon PS, Kim H, Lai CF, Tartaglia LA. The full-length leptin receptor has signaling capabilities of interleukin 6-type cytokine receptors. Proc Natl Acad Sci USA. 1996;93:8374-8.

18. Chen H, Charlat O, Tartaglia LA, Woolf EA, Weng X, Ellis SJ, Lakey ND, Culpepper J, Moore KJ, Breitbart RE, et al. Evidence that the diabetes gene encodes the leptin receptor: identification of a mutation in the leptin receptor gene in db/db mice. Cell. 1996;84:491-5.

19. Uotani S, Bjørbaek C, Tornøe J, Flier JS. Functional properties of leptin receptor isoforms: internalization and degradation of leptin and ligandinduced receptor downregulation. Diabetes. 1999;48:279-86.

20. Michael S, Henriette K, Juergen K, Marcin N, Ulf A, Rolf G, Stefan RJ, Juergen $\mathrm{S}$, Joachim T, Juergen K. Novel regulatory mechanisms for generation of the soluble leptin receptor: implications for leptin action. PLOS ONE. 2012;7:e34787.

21. Joris W, Lennart Z, Jan T. The leptin receptor complex: heavier than expected? Front Endocrinol. 2017;8:30.

22. Schaab M, Kratzsch J. The soluble leptin receptor. Best Pract Res Clin Endocrinol Metab. 2015;29:661-70.

23. Tartaglia LA, Dembski M, Weng X, Deng N, Culpepper J, Devos R, Richards GJ, Campfield LA, Clark FT, Deeds J, et al. Identification and expression cloning of a leptin receptor, OB-R. Cell. 1995;83:1263-71.

24. Zhou Y, Rui L. Leptin signaling and leptin resistance. Front Med. 2013;7:207-22.

25. White DW, Kuropatwinski KK, Devos R, Baumann H, Tartaglia LA. Leptin receptor (OB-R) signaling: cytoplasmic domain mutational analysis and evidence for receptor homo-oligomerization. J Biol Chem. 1997;272:4065-71.

26. Vaisse C, Halaas JL, Horvath CM, Darnell JE Jr, Stoffel M, Friedman JM. Leptin activation of Stat3 in the hypothalamus of wild-type and ob/ob mice but not db/db mice. Nat Genet. 1996;14:95-7.

27. Banks AS, Davis SM, Bates SH, Myers MG Jr. Activation of downstream signals by the long form of the leptin receptor. J Biol Chem. 2000;275:14563-72.

28. Horiguchi A, Oya M, Shimada T, Uchida A, Murai M. Activation of signal transducer and activator of transcription 3 in renal cell carcinoma. J Urol. 2002;168:762-5.

29. Bates SH, Stearns WH, Dundon TA, Schubert M, Tso AWK, Wang Y, Banks AS, Lavery HJ, Haq AK, Maratos-Flier E, et al. STAT3 signalling is required for leptin regulation of energy balance but not reproduction. Nature. 2003;421:856-9. 
30. Mütze J, Roth J, Gerstberger R, Hübschle T. Nuclear translocation of the transcription factor STAT5 in the rat brain after systemic leptin administration. Neurosci Lett. 2007;417:286-91.

31. Gong Y, Ishida-Takahashi R, Villanueva EC, Fingar DC, Munzberg H, Myers MG. The long form of the leptin receptor regulates STAT5 and ribosomal protein s6 via alternate mechanisms. J Biol Chem. 2007;282:31019-27.

32. Lee J-Y, Muenzberg H, Gavrilova O, Reed JA, Berryman D, Villanueva EC, Louis GW, Leinninger GM, Bertuzzi S, Seeley RJ, et al. Loss of cytokine-STAT5 signaling in the CNS and pituitary gland alters energy balance and leads to obesity. PLoS ONE. 2008;3:e1639-e1639.

33. Ji-Yeon L, Heike M, Oksana G, Reed JA, Darlene B, Villanueva EC, Louis GW, Leinninger GM, Stefano B, Seeley RJ. Loss of cytokine-STAT5 signaling in the CNS and pituitary gland alters energy balance and leads to obesity. PLoS ONE. 2008;3:e1639.

34. Pan W, Allison M, Sabatini P, Rupp A, Adams J. Transcriptional and physiological roles for STAT proteins in leptin action. Mol Metab. 2019;22:121-31.

35. Myers MG, Münzberg $H$, Leinninger $G M$, Leshan $R L$. The geometry of leptin action in the brain: more complicated than a simple ARC. Cell Metab. 2009;9:117-23.

36. Rahmouni K, Sigmund CD, Haynes WG, Mark AL. Hypothalamic ERK mediates the anorectic and thermogenic sympathetic effects of leptin. Diabetes. 2009;58:536-42.

37. Cai LI, Friedman JM. Leptin receptor activation of $\mathrm{SH} 2$ domain containing protein tyrosine phosphatase 2 modulates $\mathrm{Ob}$ receptor signal transduction. Proc Natl Acad Sci USA. 1999;96:9677-82.

38. He Z, Zhang SS, Meng Q, Li S, Zhu HH, Raquil MA, Alderson N, Zhang H, Wu J, Rui L. Shp2 controls female body weight and energy balance by integrating leptin and estrogen signals. Mol Cell Biol. 2012;32:1867-78

39. Bjorbak C, Lavery HJ, Bates SH, Olson RK, Davis SM, Flier JS, Myers MG SOCS3 mediates feedback inhibition of the leptin receptor via Tyr985. J Biol Chem. 2000;275:40649.

40. You J, Yu Y, Jiang L, Li W, Yu X, Gonzalez L, Yang G, Ke Z, Li W, Li C. Signaling through Tyr985 of leptin receptor as an age/dietdependent switch in the regulation of energy balance. Mol Cell Biol. 2010;30:1650-9.

41. Björnholm M, Münzberg H, Leshan RL, Villanueva EC, Bates SH, Louis GW, Jones JC, Ishida-Takahashi R, Bjørbaek C, Myers MG Jr. Mice lacking inhibitory leptin receptor signals are lean with normal endocrine function. J Clin Invest. 2007;117:1354-60.

42. Yang Y, Hu W, Di S, Ma Z, Fan C, Wang D, Jiang S, Li Y, Zhou Q, Li T. Tackling myocardial ischemic injury: the signal transducer and activator of transcription 3 (STAT3) at a good site. Expert Opin Ther Targets. 2017;21:215-28

43. Dandoy-Dron FO, Itier JM, Monthioux E, Bucchini D, Jami J. Tissuespecific expression of the rat insulin 1 gene in vivo requires both the enhancer and promoter regions. Differentiation. 2010;58:291-5.

44. Sano S, Itami S, Takeda K, Tarutani M, Yamaguchi Y, Miura H, Yoshikawa K, Akira S, Takeda J. Keratinocyte-specific ablation of Stat3 exhibits impaired skin remodeling, but does not affect skin morphogenesis. EMBO J. 1999;18:4657-68.

45. Cui Y, Huang L, Elefteriou F, Yang G, Shelton JM, Giles JE, Oz OK, Pourbahrami T, Lu CY, Richardson JA, et al. Essential role of STAT3 in body weight and glucose homeostasis. Mol Cell Biol. 2004;24:258-69.

46. Akira S, Nishio Y, Inoue M, Wang XJ, Shi W, Matsusaka T, Yoshida K, Sudo T, Naruto M, Kishimoto T. Molecular cloning of APRF, a novel IFN-stimulated gene factor 3 p91-related transcription factor involved in the gp130-mediated signaling pathway. Cell. 1994;77:63-71.

47. Li HC, Ma P, Xu K. Changes of signal transducer and activator of transcription-3 in the core ischemic cortex and periphery at different time points following focal cerebral ischemia reperfusion. Chin J Clin Rehab. 2006;10:88-90.

48. Hevehan DL, Miller WM, Papoutsakis ET. Differential expression and phosphorylation of distinct STAT3 proteins during granulocytic differentiation. Blood. 2002:99:1627-37.

49. Coffer PJ, Koenderman L, De Groot RP. The role of STATs in myeloid differentiation and leukemia. Oncogene. 2000;19:2511-22.

50. Aigner $P$, Just V, Stoiber D. STAT3 isoforms: alternative fates in cancer? Cytokine. 2019;118:27-34
51. Zhang H-X, Yang P-L, Li E-M, Xu L-Y. STAT3beta, a distinct isoform from STAT3. Int J Biochem Cell Biol. 2019;110:130-9.

52. $\mathrm{Ng} I H W, \mathrm{Ng} D C H$, Jans DA, Bogoyevitch MA. Selective STAT3-alpha or -beta expression reveals spliceform-specific phosphorylation kinetics, nuclear retention and distinct gene expression outcomes. Biochem J. 2012;447:125-36

53. Aigner $\mathrm{P}$, Mizutani $\mathrm{T}$, Horvath J, Eder $\mathrm{T}$, Heber $\mathrm{S}$, Lind $\mathrm{K}$, Just $\mathrm{V}$, Moll HP, Yeroslaviz A, Fischer MJM, et al. STAT3 $\beta$ is a tumor suppressor in acute myeloid leukemia. Blood Adv. 2019;3:1989-2002.

54. Maritano D, Sugrue ML, Tininini S, Dewilde S, Strobl B, Fu X, Murray-Tait $V$, Chiarle R, Poli V. The STAT3 isoforms $a$ and $\beta$ have unique and specific functions. Nat Immunol. 2004:5:401-9.

55. Schwartz MW, Woods SC, Porte D, Seeley RJ, Baskin DG. Central nervous system control of food intake. Nature. 2000:404:661-71.

56. Kwon O, Kim KW, Kim MS. Leptin signalling pathways in hypothalamic neurons. Cell Mol Life Ences. 2016;73:1457-77.

57. Cowley MA, Smart JL, Rubinstein M, Cerdán MG, Diano S, Horvath $\mathrm{TL}$, Cone RD, Low MJ. Leptin activates anorexigenic POMC neurons through a neural network in the arcuate nucleus. Nature. 2001:411:480-4.

58. Morton GJ, Cummings DE, Baskin DG, Barsh GS, Schwartz MW. Central nervous system control of food intake and body weight. Nature. 2006;443:289-95.

59. Elmquist JK, Coppari R, Balthasar N, Ichinose M, Lowell BB. Identifying hypothalamic pathways controlling food intake, body weight, and glucose homeostasis. J Comp Neurol. 2005;493:63-71.

60. Aponte $Y$, Atasoy D, Sternson SM. AGRP neurons are sufficient to orchestrate feeding behavior rapidly and without training. Nat Neurosci. 2011;14:351-5.

61. Krashes MJ, Shah BP, Koda S, Lowell BB. Rapid versus delayed stimulation of feeding by the endogenously released AgRP neuron mediators GABA, NPY, and AgRP. Cell Metab. 2013;18:588-95.

62. Schwartz MW, Seeley RJ, Woods SC, Weigle DS, Campfield LA, Burn P, Baskin DG. Leptin increases hypothalamic Pro-opiomelanocortin mRNA expression in the rostral arcuate nucleus. Diabetes. 1997:46:2119-23.

63. Mizuno TM, Mobbs CV. Hypothalamic agouti-related protein messenger ribonucleic acid is inhibited by leptin and stimulated by fasting*. Endocrinology. 1999;140:814-7.

64. Bewick GA, Gardiner JV, Dhillo WS, Kent AS, White NE, Webster Z, Ghatei MA, Bloom SR. Postembryonic ablation of AgRP neurons in mice leads to a lean, hypophagic phenotype. FASEB J. 2005;19:1680-2.

65. Gropp E, Shanabrough M, Borok E, Xu AW, Janoschek R, Buch T, Plum L, Balthasar N, Hampel B, Waisman A, et al. Agouti-related peptide-expressing neurons are mandatory for feeding. Nat Neurosci. 2005;8:1289-91.

66. Balthasar N, Coppari R, McMinn J, Liu SM, Lee CE, Tang V, Kenny CD, McGovern RA, Chua SC Jr, Elmquist JK, Lowell BB. Leptin receptor signaling in POMC neurons is required for normal body weight homeostasis. Neuron. 2004:42:983-91.

67. Üner AG, Keçik O, Quaresma PGF, De Araujo TM, Lee H, Li W, Kim HJ, Chung M, Bjørbæk C, Kim Y-B. Role of POMC and AgRP neuronal activities on glycaemia in mice. Sci Rep. 2019;9:13068-13068.

68. Kim KW, Zhao L, Donato J Jr, Kohno D, Xu Y, Elias CF, Lee C, Parker $\mathrm{KL}$, Elmquist JK. Steroidogenic factor 1 directs programs regulating diet-induced thermogenesis and leptin action in the ventral medial hypothalamic nucleus. Proc Natl Acad Sci USA. 2011;108:10673-8.

69. Roh E, Song DK, Kim M-S. Emerging role of the brain in the homeostatic regulation of energy and glucose metabolism. Exp Mol Med. 2016:48:e216-e216.

70. Kitamura T, Feng Y, Ido Kitamura Y, Chua SC, Xu AW, Barsh GS, Rossetti L, Accili D. Forkhead protein FoxO1 mediates Agrp-dependent effects of leptin on food intake. Nat Med. 2006:12:534-40.

71. Xu L, Li H, Zhou G, Lu W, Yang R, Liu H, Yang G. DNA-binding activity of STAT3 increased in hypothalamus of DIO mice; the reduction of STAT3 phosphorylation may facilitate leptin signaling. Biochem Biophys Res Commun. 2018:505:229-35.

72. Münzberg H, Huo L, Nillni EA, Hollenberg AN, Bjørbæk C. Role of signal transducer and activator of transcription 3 in regulation of hypothalamic proopiomelanocortin gene expression by leptin. Endocrinology. 2003;144:2121-31. 
73. Gao Q, Wolfgang MJ, Neschen S, Morino K, Horvath TL, Shulman Gl, Fu $X Y$. Disruption of neural signal transducer and activator of transcription 3 causes obesity, diabetes, infertility, and thermal dysregulation. Proc Natl Acad Sci. 2004;101:4661-6.

74. Morrison CD. Leptin inhibits hypothalamic Npy and Agrp gene expression via a mechanism that requires phosphatidylinositol 3-OH-kinase signaling. Am J Physiol Endocrinol Metab. 2005;289:E1051.

75. Münzberg H, Jobst EE, Bates SH, Jones J, Villanueva E, Leshan R, Björnholm M, Elmquist J, Sleeman M, Cowley MA, Myers MG Jr. Appropriate inhibition of orexigenic hypothalamic arcuate nucleus neurons independently of leptin receptor/STAT3 signaling. J Neurosci. 2007;27:69-74.

76. Kaelin CB, Gong L, Xu AW, Yao F, Kristin H, Morton GJ, Schwartz MW, Barsh GS, Mackenzie RG. Signal transducer and activator of transcription (stat) binding sites but not stat3 are required for fasting-induced transcription of agouti-related protein messenger ribonucleic acid. Mol Endocrinol. 2006;20:2591-602.

77. Xu AW, Ste-Marie L, Kaelin CB, Barsh GS. Inactivation of signal transducer and activator of transcription 3 in proopiomelanocortin (Pomc) neurons causes decreased pomc expression, mild obesity, and defects in compensatory refeeding. Endocrinology. 2007;148:72-80.

78. Gong L, Yao F, Hockman K, Heng HH, Morton GJ, Takeda K, Akira S, Low MJ, Rubinstein M, MacKenzie RG. Signal transducer and activator of transcription-3 is required in hypothalamic agouti-related protein/neuropeptide $Y$ neurons for normal energy homeostasis. Endocrinology. 2008; 149:3346-54.

79. Toda C, Santoro A, Kim JD, Diano S. POMC neurons: from birth to death. Annu Rev Physiol. 2017;79:209-36.

80. Yoo JY, Huso DL, Nathans D, Desiderio S. Specific ablation of Stat3 $\beta$ distorts the pattern of Stat3-responsive gene expression and impairs recovery from endotoxic shock. Cell. 2002;108:331-44.

81. Liu L, McBride KM, Reich NC. STAT3 nuclear import is independent of tyrosine phosphorylation and mediated by importin-alpha3. Proc Natl Acad Sci USA. 2005;102:8150-5.

82. Benekli M, Baumann H, Wetzler M. Targeting signal transducer and activator of transcription signaling pathway in leukemias. J Clin Oncol. 2009:27:4422-32.

83. Hu D, Wan L, Chen M, Caudle Y, LeSage G, Li Q, Yin D. Essential role of IL-10/STAT3 in chronic stress-induced immune suppression. Brain Behav Immun. 2014;36:118-27.

84. Yokogami K, Wakisaka S, Avruch J, Reeves SA. Serine phosphorylation and maximal activation of STAT3 during CNTF signaling is mediated by the rapamycin target mTOR. Curr Biol. 2000;10:47-50.

85. Zhuang S. Regulation of STAT signaling by acetylation. Cell Signal. 2013:25:1924-31.

86. Irie-Sasaki J, Sasaki T, Matsumoto W, Opavsky A, Penninger JM. CD45 is a JAK phosphatase and negatively regulates cytokine receptor signalling. Nature. 2001:409:349-54.

87. Alshaker H, Sacco K, Alfraidi A, Muhammad A, Winkler M, Pchejetski D. Leptin signalling, obesity and prostate cancer: molecular and clinical perspective on the old dilemma. Oncotarget. 2015;6:35556-63.

88. Hung MH, Tai WT, Shiau CW, Chen KF. Downregulation of signal transducer and activator of transcription 3 by sorafenib: a novel mechanism for hepatocellular carcinoma therapy. World J Gastroenterol. 2014;20:15269-74.

89. Zhang X, Guo A, Yu J, Possemato A, Chen Y, Zheng W, Polakiewicz RD, Kinzler KW, Vogelstein B, Velculescu VE, Wang ZJ. Identification of STAT3 as a substrate of receptor protein tyrosine phosphatase T. Proc Natl Acad Sci. 2007;104:4060-4.

90. Lee JH, Kim C, Sethi G, Ahn KS. Brassinin inhibits STAT3 signaling pathway through modulation of PIAS-3 and SOCS-3 expression and sensitizes human lung cancer xenograft in nude mice to paclitaxel. Oncotarget. 2015;6:6386-405.

91. Liang Z, Wu G, Fan C, Xu J, Yang Y. The emerging role of signal transducer and activator of transcription 3 in cerebral ischemic and hemorrhagic stroke. Prog Neurobiol. 2016;137:1-16.

92. Coppes RP. SOCS box: fine-tuning inflammatory responses. Blood. 2007;110:1403-4.

93. Plum L, Lin HV, Dutia R, Tanaka J, Aizawa KS, Matsumoto M, Kim AJ, Cawley NX, Paik JH, Loh YP, et al. The obesity susceptibility gene Cpe links FoxO1 signaling in hypothalamic pro-opiomelanocortin neurons with regulation of food intake. Nat Med. 2009;15:1195-201.
94. Yang G, Lim CY, Li C, Xiao X, Radda GK, Li C, Cao X, Han W. FoxO1 inhibits leptin regulation of pro-opiomelanocortin promoter activity by blocking STAT3 interaction with specificity protein 1. J Biol Chem. 2009;284:3719.

95. Liu J, Yang X, Yu S, Zheng R. The leptin resistance. Adv Exp Med Biol. 2018;1090:145-63.

96. Scarpace PJ, Matheny M, Tümer N, Cheng KY, Zhang Y. Leptin resistance exacerbates diet-induced obesity and is associated with diminished maximal leptin signalling capacity in rats. Diabetologia. 2005;48:1075-83.

97. Banks WA, Coon AB, Robinson SM, Moinuddin A, Shultz JM, Nakaoke $\mathrm{R}$, Morley JE. Triglycerides induce leptin resistance at the blood-brain barrier. Diabetes. 2004;53:1253-60.

98. Izquierdo AG, Crujeiras AB, Casanueva FF, Carreira MC. Leptin, obesity, and leptin resistance: where are we 25 years later? Nutrients. 2019;11:2704.

99. Hileman SM, Pierroz DD, Masuzaki H, Bjørbaek C, El-Haschimi K, Banks WA, Flier JS. Characterizaton of short isoforms of the leptin receptor in rat cerebral microvessels and of brain uptake of leptin in mouse models of obesity. Endocrinology. 2002;143:775-83.

100. Crujeiras AB, Carreira MC, Cabia B, Andrade S, Amil M, Casanueva FF. Leptin resistance in obesity: an epigenetic landscape. Life Sci. 2015;140:57-63.

101. Banks WA, Clever CM, Farrell CL. Partial saturation and regional variation in the blood-to-brain transport of leptin in normal weight mice. Am J Physiol-Endocrinol Metab. 2000;278:E1158-65.

102. Banks WA, Niehoff ML, Martin D, Farrell CL. Leptin transport across the blood-brain barrier of the Koletsky rat is not mediated by a product of the leptin receptor gene. Brain Res. 2002;950:130-6.

103. Harrison L, Schriever SC, Feuchtinger A, Kyriakou E, Baumann P, Pfuhlmann K, Messias AC, Walch A, Tschöp MH, Pfluger PT. Fluorescent blood-brain barrier tracing shows intact leptin transport in obese mice. Int J Obes. 2019:43:1305-18.

104. Banks WA. Enhanced leptin transport across the blood-brain barrier by alpha 1-adrenergic agents. Brain Res. 2001;899:209-17.

105. Nonaka N, Hileman SM, Shioda S, Vo TQ, Banks WA. Effects of lipopolysaccharide on leptin transport across the blood-brain barrier. Brain Res. 2004;1016:58-65.

106. Banks WA, Farrell CL. Impaired transport of leptin across the bloodbrain barrier in obesity is acquired and reversible. Am J Physiol Endocrinol Metab. 2003;285:10-5.

107. Banks WA, Coon AB, Robinson SM, Moinuddin A. Triglycerides induce leptin resistance at the blood-brain barrier. Diabetes. 2004;53:1253-60.

108. Kastin AJ, Akerstrom V. Fasting, but not adrenalectomy, reduces transport of leptin into the brain. Peptides. 2000;21:679-82.

109. Heike MN, Flier JS, Christian B. Region-specific leptin resistance within the hypothalamus of diet-induced obese mice. Endocrinology. 2004;145:11.

110. Martin SS, Qasim A, Reilly MP. Leptin resistance: a possible interface of inflammation and metabolism in obesity-related cardiovascular disease. J Am Coll Cardiol. 2008;52:1201-10.

111. Ropelle ER, Flores MB, Cintra DE, Rocha GZ, Pauli JR, Morari J, de Souza CT, Moraes JC, Prada PO, Guadagnini D, et al. IL-6 and IL-10 anti-inflammatory activity links exercise to hypothalamic insulin and leptin sensitivity through IKKbeta and ER stress inhibition. PLOS Biol. 2010;8:e1000465.

112. Ren D, Zhou Y, Morris D, Li M, Li Z, Rui L. Neuronal SH2B1 is essential for controlling energy and glucose homeostasis. J Clin Invest. 2007;117:397-406.

113. Bochukova EG, Huang N, Keogh J, Henning E, Purmann C, Blaszczyk K, Saeed S, Hamilton-Shield J, Clayton-Smith J, O'Rahilly S, et al. Large, rare chromosomal deletions associated with severe early-onset obesity. Nature. 2010;463:666-70.

114. Morris DL, Cho KW, Rui L. Critical role of the Src homology 2 (SH2) domain of neuronal $\mathrm{SH} 2 \mathrm{~B} 1$ in the regulation of body weight and glucose homeostasis in mice. Endocrinology. 2010;151:3643-51.

115. Meng Q, Cai D. Defective hypothalamic autophagy directs the central pathogenesis of obesity via the IkB kinase $\beta$ (IKK $\beta$ )/NF-kB pathway. J Biol Chem. 2011;286:32324-32.

116. Wenying Q, Hyun-Kyong K, Eun-Yi M, Sung KS, Soo CC, Masaaki K, Taek JY, Moon-Kyu L, Kwang-Won K, Min-Seon K. Role of hypothalamic 
proopiomelanocortin neuron autophagy in the control of appetite and leptin response. Endocrinology. 2012;4:1817-26.

117. Kaushik S, Rodriguez-Navarro Jose A, Arias E, Kiffin R, Sahu S, Schwartz Gary J, Cuervo Ana M, Singh R. Autophagy in hypothalamic AgRP neurons regulates food intake and energy balance. Cell Metab. 2011;14:173-83.

118. Goldstein N, Haim Y, Mattar P, Hadadi-Bechor S, Maixner N, Kovacs P, Blüher M, Rudich A. Leptin stimulates autophagy/lysosomerelated degradation of long-lived proteins in adipocytes. Adipocyte. 2019;8:51-60

119. Ozcan L, Ergin AS, Lu A, Chung J, Sarkar S, Nie D, Myers MG Jr, Ozcan $U$. Endoplasmic reticulum stress plays a central role in development of leptin resistance. Cell Metab. 2009:9:35-51.

120. Zhang X, Zhang G, Zhang H, Karin M, Bai H, Cai D. Hypothalamic IKKbeta/NF-kappaB and ER stress link overnutrition to energy imbalance and obesity. Cell. 2008;135:61-73.

121. Shoelson SE, Lee J, Goldfine AB. Inflammation and insulin resistance. J Clin Invest. 2006;116:1793-801.

122. Xu C, Bailly-Maitre B, Reed JC. Endoplasmic reticulum stress: cell life and death decisions. J Clin Invest. 2005:115:2656-64.

123. Schneeberger $M$, Dietrich $M O$, Sebastián $D$, Imbernón $M$, Castaño $C$, Garcia A, Esteban Y, Gonzalez-Franquesa A, Rodríguez IC, Bortolozzi A, et al. Mitofusin 2 in POMC neurons connects ER stress with leptin resistance and energy imbalance. Cell. 2013;155:172-87.

124. Thaler JP, Yi CX, Schur EA, Guyenet SJ, Hwang BH, Dietrich MO, Zhao X, Sarruf DA, Izgur V, Maravilla KR, et al. Obesity is associated with hypothalamic injury in rodents and humans. J Clin Invest. 2012;122:153-62.

125. Zhang X, Zhang G, Zhang H, Karin M, Bai H, Cai D. Hypothalamic IKKß/ NF-KB and ER stress link overnutrition to energy imbalance and obesity. Cell. 2008;135:61-73.

126. Williams KW, Liu T, Kong X, Fukuda M, Deng Y, Berglund ED, Deng Z, Gao Y, Liu T, Sohn J-W, et al. Xbp1s in Pomc neurons connects ER stress with energy balance and glucose homeostasis. Cell Metab. 2014;20:471-82

127. White $C L$, Whittington $A$, Barnes MJ, Wang Z, Bray GA, Morrison CD. HF diets increase hypothalamic PTP1B and induce leptin resistance through both leptin-dependent and -independent mechanisms. Am J Physiol Endocrinol Metab. 2009;296:E291-299.

128. Zabolotny JM, Kim YB, Welsh LA, Kershaw EE, Neel BG, Kahn BB. Proteintyrosine phosphatase $1 \mathrm{~B}$ expression is induced by inflammation in vivo. J Biol Chem. 2008;283:14230-41.

129. Hosoi T, Sasaki M, Miyahara T, Hashimoto C, Matsuo S, Yoshii M, Ozawa K. Endoplasmic reticulum stress induces leptin resistance. Mol Pharmacol. 2008;74:1610-9.

130. Park S, Aintablian A, Coupe B, Bouret SG. The endoplasmic reticulum stress-autophagy pathway controls hypothalamic development and energy balance regulation in leptin-deficient neonates. Nat Commun. 1914;2020:11

131. Mainardi M, Pizzorusso T, Maffei M. Environment, leptin sensitivity, and hypothalamic plasticity. Neural Plast. 2013;2013:438072-438072.

132. Knight ZA, Hannan KS, Greenberg ML, Friedman JM. Hyperleptinemia is required for the development of leptin resistance. PLOS ONE. 2010:5:e11376.

133. Ernst MB, Wunderlich CM, Hess S, Paehler M, Mesaros A, Koralov SB, Kleinridders A, Husch A, Münzberg H, Hampel B, et al. Enhanced Stat3 activation in POMC neurons provokes negative feedback inhibition of leptin and insulin signaling in obesity. J Neurosci. 2009;29:11582-93.

134. Tam J, Cinar R, Liu J, Godlewski G, Wesley D, Jourdan T, Szanda G, Mukhopadhyay B, Chedester L, Liow JS. Peripheral cannabinoid-1 receptor inverse agonism reduces obesity by reversing leptin resistance. Cell Metab. 2012;16:167-79.

135. Chen K, Li F, Li J, Cai H, Strom S, Bisello A, Kelley DE, Friedman-Einat $M$, Skibinski GA, McCrory MA, et al. Induction of leptin resistance through direct interaction of C-reactive protein with leptin. Nat Med. 2006;12:425-32.

136. Milagro Fl, Campión J, García-Díaz DF, Goyenechea E, Paternain L, Martínez JA. High fat diet-induced obesity modifies the methylation pattern of leptin promoter in rats. J Physiol Biochem. 2009;65:1-9.

137. Caro JF, Kolaczynski JW, Nyce MR, Ohannesian JP, Opentanova I, Goldman WH, Lynn RB, Zhang P-L, Sinha MK, Considine RV. Decreased cerebrospinal-fluid/serum leptin ratio in obesity: a possible mechanism for leptin resistance. Lancet. 1996;348:159-61.

138. Vaisse C, Halaas JL, Horvath CM, Darnell JE, Stoffel M, Friedman JM. Leptin activation of Stat3 in the hypothalamus of wild-type and ob/ob mice but not db/db mice. Nat Genet. 1996;14:95-7.

139. Balland E, Cowley MA. New insights in leptin resistance mechanisms in mice. Front Neuroendocrinol. 2015;39:S0091302215300078.

140. Gamber KM, Huo L, Ha S, Hairston JE, Greeley S, Bjørbæk C. Over-expression of leptin receptors in hypothalamic POMC neurons increases susceptibility to diet-induced obesity. PLoS ONE. 2012;7:e30485.

141. Kleinridders A, Schenten D, Könner AC, Belgardt BF, Mauer J, Okamura T, Wunderlich FT, Medzhitov R, Brüning JC. MyD88 signaling in the CNS is required for development of fatty acid-induced leptin resistance and diet-induced obesity. Cell Metab. 2009;10:249-59.

142. Enriori PJ, Evans AE, Sinnayah P, Jobst EE, Tonelli-Lemos L, Billes SK, Glavas MM, Grayson BE, Perello M, Nillni EA, et al. Diet-induced obesity causes severe but reversible leptin resistance in arcuate melanocortin neurons. Cell Metab. 2007:5:181-94.

143. Halaas JL, Boozer C, Blair-West J, Fidahusein N, Denton DA, Friedman JM. Physiological response to long-term peripheral and central leptin infusion in lean and obese mice. Proc Natl Acad Sci USA. 1997:94:8878-83.

144. Lin S, Storlien LH, Huang XF. Leptin receptor, NPY, POMC mRNA expression in the diet-induced obese mouse brain. Brain Res. 2000;875:89-95.

145. El-Haschimi K, Pierroz DD, Hileman SM, Bjørbaek C, Flier JS. Two defects contribute to hypothalamic leptin resistance in mice with diet-induced obesity. J Clin Invest. 2000;105:1827-32.

146. Lambert PD, Anderson KD, Sleeman MW, Wong V, Tan J. Ciliary neurotrophic factor activates leptin-like pathways and reduces body fat, without. Proc Natl Acad Sci USA. 2001;98:4652.

147. Thomas H, Elke T, Anna W, Joachim R, Susanne K, Wolfgang M. Leptin-induced nuclear translocation of STAT3 immunoreactivity in hypothalamic nuclei involved in body weight regulation. J Neurosci. 2001;21:2413-24

148. Sáinz N, Barrenetxe J, Moreno-Aliaga MJ, Martínez JA. Leptin resistance and diet-induced obesity: central and peripheral actions of leptin. Metabolism. 2015;64:35-46.

149. Van HJK, Leslie E, Eric F, Andries K, Adan RAH, La FSE, Zane A. Differential modulation of arcuate nucleus and mesolimbic gene expression levels by central leptin in rats on short-term high-fat high-sugar diet. PLoS ONE. 2014;9:e87729.

150. Martin TL, Alquier T, Asakura K, Furukawa N, Preitner F, Kahn BB. Diet-induced obesity alters AMP kinase activity in hypothalamus and skeletal muscle. J Biol Chem. 2006;281:18933-41.

151. Flier JS, Maratos-Flier E. Leptin's physiologic role: does the emperor of energy balance have no clothes? Cell Metab. 2017;26:24-6.

152. Ravussin Y, Leibel RL, Ferrante AW Jr. A missing link in body weight homeostasis: the catabolic signal of the overfed state. Cell Metab. 2014;20:565-72.

\section{Publisher's Note}

Springer Nature remains neutral with regard to jurisdictional claims in published maps and institutional affiliations. 